\title{
Annual report October 1999 to September 2000
}

This has been a very successful year for Thorax. The number of submissions to the journal has risen again, particularly for original research papers which have increased by $25 \%$ over the last two years (table 1 ). Thorax continues to attract original contributions from all over the world (table 2) and, from the Editors' perspective, it is clear that not only the quantity but also the quality of material now being submitted to the journal is substantially higher than when we took over the editorship five years ago. The impact factor for the journal has also risen substantially over the last two years, ${ }^{1}$ and whether this measure drives or reflects the quality and number of our submissions is hard to tell. However, table 1 shows that, allowing a two year lag for impact factor figures to influence research submissions (for example, the 1996 impact factor is released in summer 1997 and so influences submissions in the year from October 1997 to September 1998), original research submissions to the journal went down after the release of an impact factor figure that had fallen, and went up after release of an impact factor figure that had increased. While there are clear arguments as to why impact factors are not

Table 1 Impact factor and articles submitted by category

\begin{tabular}{lrrrrrr}
\hline & 1995 & 1996 & 1997 & 1998 & 1999 & 2000 \\
\hline Impact factor & 2.13 & 1.96 & 2.31 & 2.86 & 3.44 & \\
Original research & & & & & & \\
Full papers & 493 & 415 & 411 & 398 & 453 & 505 \\
Short papers & 48 & 51 & 40 & 31 & 36 & 34 \\
Rapid communications & - & 5 & 5 & 7 & 3 & 6 \\
Case reports & 252 & 247 & 212 & 211 & 149 & 165 \\
Editorials/reviews & 38 & 38 & 53 & 81 & 57 & 56 \\
Review series & 18 & 31 & 26 & 13 & 19 & 14 \\
Supplement articles & 16 & 41 & 29 & 17 & 16 & 46 \\
Case report commentaries & 7 & 11 & 7 & 7 & 0 & 0 \\
Letters & N/A & 50 & 55 & 72 & 79 & 96 \\
Total & & & & & & \\
& 872 & 889 & 838 & 837 & 812 & 922 \\
\hline
\end{tabular}

Table 2 Geographical distribution of submissions

\begin{tabular}{lrrrrrr}
\hline & 1995 & 1996 & 1997 & 1998 & 1999 & 2000 \\
\hline UK & 291 & 320 & 303 & 265 & 326 & 348 \\
Western Europe & 266 & 264 & 236 & 242 & 230 & 268 \\
Spain & 46 & 42 & 45 & 44 & 37 & 38 \\
The Netherlands & 51 & 44 & 49 & 41 & 40 & 51 \\
Italy & 38 & 48 & 19 & 38 & 40 & 36 \\
France & 27 & 28 & 24 & 27 & 26 & 34 \\
Turkey & 13 & 14 & 22 & 20 & 17 & 27 \\
Israel & 20 & 17 & 15 & 10 & 13 & 8 \\
Eire & 10 & 8 & 7 & 5 & 2 & 5 \\
Switzerland & 10 & 13 & 9 & 5 & 5 & 9 \\
Germany & 16 & 26 & 23 & 20 & 29 & 31 \\
Belgium & 17 & 12 & 11 & 10 & 10 & 5 \\
Greece & 7 & 7 & 6 & 15 & 6 & 12 \\
Austria & 7 & 5 & 5 & 3 & 4 & 10 \\
Portugal & 3 & 0 & 0 & 2 & 0 & 0 \\
Malta & 1 & 0 & 0 & 2 & 1 & 1 \\
Andorra & 0 & 0 & 0 & 0 & 0 & 1 \\
USA and Canada & 101 & 71 & 84 & 76 & 81 & 87 \\
Japan & 65 & 53 & 64 & 46 & 54 & 56 \\
Australasia & 38 & 31 & 60 & 48 & 38 & 60 \\
Scandinavia & 36 & 32 & 39 & 36 & 38 & 41 \\
Asia & 34 & 26 & 26 & 35 & 30 & 39 \\
Eastern Europe & 7 & 10 & 3 & 6 & 4 & 9 \\
South America & 14 & 10 & 3 & 3 & 1 & 5 \\
Africa & 7 & 4 & 4 & 3 & 3 & 4 \\
Middle East & 13 & 5 & 9 & 5 & 7 & 5 \\
\hline
\end{tabular}

Table 3 Decision of papers submitted 1999/2000 as at 30 September 2000

\begin{tabular}{lccc}
\hline & Case reports & Papers & Short papers \\
\hline Total & 165 & 505 & 34 \\
Rejected & $133(81 \%)$ & $302(60 \%)$ & $25(73 \%)$ \\
Accepted & $3(2 \%)$ & $62(12 \%)$ & $5(15 \%)$ \\
Pending & $29(17 \%)$ & $139(27.5 \%)$ & $4(12 \%)$ \\
Withdrawn & & $2(0.5 \%)$ & \\
\hline
\end{tabular}

Table 4 Median time to first decision (days)

\begin{tabular}{llllll}
\hline & $1995 / 6$ & $1996 / 7$ & $1997 / 8$ & $1998 / 9$ & $1999 / 2000$ \\
\hline Full papers & 74 & 44.5 & 56 & 48.5 & 56 \\
Short papers & 82 & 38 & 24 & 11.5 & 28
\end{tabular}

necessarily good measures of journal quality, ${ }^{2}$ this observation indicates that impact factors do say something about the standard of the journal, at least as perceived by those who submit original research.

As in all our years as editors, ${ }^{3-6}$ we have this year pursued a highly selective policy on paper acceptance, and this year's figures indicate that we are accepting about $20-25 \%$ of papers submitted to the journal (table 3). In the light of the increasing numbers submitted to the journal, this proportion is likely to fall in coming years. Our median time taken to reach a decision on full papers remains at 7-8 weeks, and four weeks for short papers (table 4). This year we have also continued with the definitive review series on rare diseases ${ }^{7}$ and have started a new series on the paediatric origins of adult lung disease. ${ }^{8}$

During this year, as ever, we have been helped enormously by the associate editors, the advisory board, editorial assistants, and by our managers at BMJ Publications. Special thanks are due to Robert Winter, who for many years has edited the case reports in the journal in addition to a share of original research papers; we thank him for his tireless work and invariably thoughtful and perceptive advice. Rachel Orme, one of our editorial assistants for the last three years, also leaves us this year and we wish her well for the future. Our journal is as ever heavily dependent on the goodwill and hard work of our reviewers, and to them we express our thanks; their names are listed on page 1072. Our ultimate thanks go, however, to the people who send us papers since it is they who ultimately determine the quality and interest of the journal. Please continue to send us your best work.

\section{J BRITTON A J KNOX Executive Editors}

1 Britton J, Knox A. Journal Impact Factors for 1999. Thorax 2000;55:725. 2 Seglen PO. Why the impact factor of journals should not be used for evaluating research. BMF 1997;314:497.

3 Britton JR, Knox AJ. Annual report October 1995 to September 1996. Tho$\operatorname{rax} 1996 ; 51: 1177$

4 Knox AJ, Britton J. Annual report October 1996 to September 1997. Thorax 1997;52:1023.

5 Knox AJ, Britton J. Rising impact, fast review: Annual report October 1997 to September 1998. Thorax 1999;54:5-6.

6 Britton J, Knox AJ, Orme RLJ, et al. Annual report October 1998 to September 1999. Thorax 2000;55:2-3.

7 Tattersfield AE, du Bois RM. Rare diseases: introduction. Thorax 1999;54:

253. 55:585-6. 